\title{
Assessment of date palm pollen supplementation on productivity, digestibility, immune response, and intestinal and hepatic morphology of Egyptian fayoumi laying Hens
}

\begin{abstract}
This study was carried out to assess the influence of date palm pollen supplement on the productive performance, digestibility, immune response, and some morphological parameters of Fayoumi laying hens. One-hundred and fifty hens of 30-weeks of age were included in the study. The treated group was supplemented with $0.5 \%$ date palm pollen. The experiment was divided into three periods; each of them was 4 weeks. The obtained results showed a significant improvement in the cumulative egg production of the treated group. Eggs weight, mass and feed conversion revealed significant differences with date palm pollen supplementation. The digestibility of nutrients was increased through the experimental period, accompanied by positive morphological changes in the intestinal lumen, villi length, and crypt depth. Moreover, the immune response was significantly improved in the treated group. Finally we could recommend the supplementation of date palm pollen for laying hens through the production period and during stress.
\end{abstract}

Keywords: date palm pollen, digestibility, immune response, intestinal morphology, liver
Volume 7 Issue 4 - 2018

\author{
Mohamed A Mousa,' Ramy KA Sayed, ${ }^{2}$ \\ Ahmed S Osman, ${ }^{3}$ Haitham H Sayed ${ }^{4}$ \\ 'Department of Nutrition and Clinical Nutrition, Sohag \\ University, Egypt \\ ${ }^{2}$ Department of Anatomy and Embryology, Sohag University, \\ Egypt \\ ${ }^{3}$ Department of Biochemistry, Sohag University, Egypt \\ ${ }^{4}$ Department of Microbiology, Sohag University, Egypt
}

\begin{abstract}
Correspondence: Mohamed A Mousa, Department of Nutrition and Clinical Nutrition, Faculty of Veterinary Medicine, Sohag University, 82524, Sohag, Egypt, Tel 00201006741916,
\end{abstract} Email dr_m_mousa@yahoo.com

Received: May 29, 2018 | Published: July 03, 2018

\section{Introduction}

The concept of using herbal plants as alternative products for growth promotor and immune modulator has been spread worldwide, where it replaces the antibiotics in raising broilers to avoid bacterial resistances. Extract of the date palm pollen (DPP) was used ti improve male fertility in traditional medicine. ${ }^{1}$ It contains a lot of natural antioxidants, ${ }^{2}$ as Polyphenolics and flavonoids, ${ }^{3}$ which protect active tissues such as testes and ovaries. ${ }^{4,5}$ The DPP is used as a feed additive in broilers diets to improve body weight gain, ${ }^{6,7}$ while aqueous extract of DPP have a significant variation on eggs production and weight, and on female reproductive tract weight. ${ }^{8,9}$ Previous studies revealed the protective effects of DPP in progression of the damagedinduced intestinal epithelium of mice and rats. ${ }^{10}$ The small intestine structure is related to digestion and absorption processes. ${ }^{11}$ The wall of small intestine is composed of the mucosa that is thrown into regularly arranged villi, which are longest in the duodenum. This mucosa contains simple tubular glands, smooth muscle fibers, and numerous lymphocytes. As well, the intestinal wall consists of submucosa, muscularis, and serosa layers. ${ }^{12,13}$ There are a little and discrete information about the effect of the natural antioxidants on the digestibility and morphological structure of intestinal layers, as well as their effects on the immune response. Therefore, the main purpose of our work is to determine the impacts of DPP supplementation on the productivity, digestibility, immune response, and some intestinal morphological parameters of Fayoumi layer hens during production.

\section{Materials and methods}

\section{Experimental design}

This work was done regarding the regulation of Nutrition and Clinical Nutrition Department, Faculty of Veterinary Medicine, Sohag University, Egypt. A total of 150 Fayoumi laying hens, 30 weeks-old were randomly divided into two groups (75 per each); control group (CG) and treated group (TG) after 1-wk of adaptation period. The groups were subdivided into three replicates $(25$ per each) (Table 1). Hens of control group were fed a basal diet, while treated group received a basal diet supplemented with $0.5 \%$ DPP. Ingredients and nutrient analysis of basal diet are illustrated in Table 2. The lighting period was $17 \mathrm{hrs}$ per day. Laying ration and clean water were given ad libitum. The temperature average value during the experiment period was $34.50 \pm 3.5^{\circ} \mathrm{C}$, where the experiment was conducted from June $20^{\text {th }}$ to September $20^{\text {th }}$.

Table I Experimental design

\begin{tabular}{|c|c|c|}
\hline Parameters & $\begin{array}{l}\text { Control groups (C) } \\
\text { (No supplements) }\end{array}$ & $\begin{array}{l}\text { Treated group }(T) \\
\text { (supplemented with } \\
0.5 \% \text { DPP) }\end{array}$ \\
\hline No. of birds & 75 fayoumi-laying hens & 75 fayoumi-laying hens \\
\hline No. of replicates & 3 & 3 \\
\hline Adaptation period & One week (29-wk-old) & \\
\hline \multirow[t]{2}{*}{ Age of start } & 30 wks-age & 30 wks-age \\
\hline & $\begin{array}{l}\text { (Phase I) 30-33 wks- } \\
\text { old }\end{array}$ & (Phase I) 30-33 wks-old \\
\hline \multirow[t]{2}{*}{ Periods } & $\begin{array}{l}\text { (Phase 2) 34-37 wks- } \\
\text { old }\end{array}$ & (Phase 2) 34-37 wks-old \\
\hline & (Phase 3) 38-4I wks-old & (Phase 3) 38-4I wks-old \\
\hline
\end{tabular}

\section{Performance and digestibility}

Live body weights were measured at the beginning and the end of the experiment to estimate growth weight. Feed intake was estimated daily. During this work, health status, morbidity and mortality were 
monitored and recorded for both groups. The production of eggs and its weight were recorded daily throughout the period of the experiment.

Table 2 Diet composition and calculated analysis

\begin{tabular}{ll}
\hline Ingredients & $\%$ \\
\hline Corn & 64.1 \\
Soybean meal & 20 \\
Wheat bran & 4 \\
Lime stone & 9.3 \\
Premix I & 0.3 \\
Common salt & 0.3 \\
Mono-calcium phosphate & 1.5 \\
Slack (sand or DPP) & 0.5 \\
Total & 100 \\
Chemical analysis & \\
CP & 16.16 \\
EE & 2.77 \\
CF & 2.64 \\
Ash & 13.2 \\
Ca & 3.93 \\
Available P & 0.29 \\
Lysine & 0.9 \\
Methionine & 0.26 \\
ME (Kcal/kg) & 2710 \\
\hline the miner and & \\
\hline
\end{tabular}

'premix provides the mineral and vitamins according to the recommended levels of NRC, 1994.

${ }^{2}$ ME was estimated according to NRC, 1994.

Data percentage expressed on dry matter basis.

After the experimental period, twenty hens were placed into separate places, 10 birds per each group, in order to estimate the apparent digestibility of nutrients. The excrement samples were collected twice daily. These samples were oven-dried according to the Association of Official Agricultural Chemists AOAC, ${ }^{14}$ and then were ground and kept for further chemical analyses. We use $\mathrm{Cr} 2 \mathrm{O} 3$ method for determination of nutrients digestibility $(0.25 \% \mathrm{Cr} 2 \mathrm{O} 3$ of diet) as indicator. ${ }^{15}$

\section{Laboratory analyses}

Chemical analyses of crude potein according to kjldahle method, ether extract and crude fiber according to filter page method were done for both samples of feed and excrement, using the procedures of AOAC. ${ }^{14}$

\section{Evaluation of immune response}

Hens 38 wks-old were assigned for evaluation of immune response. In our work, $3 \%$ suspension of washed sheep red blood cells (SRBCs) was used as antigen with multi-determinant, non-pathogenic action and stimulates T-cell. ${ }^{16}$ Hens were injected with SRBC, $1 \mathrm{ml} /$ hen then a booster dose of SRBC was injected after 14 days from the first dose. Blood samples were collected at $7^{\text {th }}$ and $14^{\text {th }}$ days after the $1^{\text {st }}$ and the $2^{\text {nd }}$ injection. The serum was stored at $-20^{\circ} \mathrm{C}$ to be tested later. In order to determine antibodies levels, hemaglutination test was used. Serum was incubated at $56^{\circ} \mathrm{C}$ for $30 \mathrm{~min}$, and then was analyzed for total antibodies, mercaptoethanol-sensitive (IgM) and mercaptoethanolresistant (IgG) against SRBCs according to Yamamoto \& Glick $^{17}$ and Qureshi \& Havenstein. ${ }^{18}$

\section{Histological examination}

For histological investigation, three birds from both control and treated groups were sacrificed by cervical subluxation in Anatomy and Embryology Department, Faculty of Veterinary Medicine, Sohag University, Egypt. The birds were transcardially perfused with saline after complete bleeding, followed by fixation with $10 \%$ neutral buffer formalin. Small pieces from both duodenum and liver were dissected and immersed in formalin for $24 \mathrm{hr}$. After proper fixation, the specimens were extensively washed in $70 \%$ ethanol $(2 \times 24 \mathrm{hr})$ to remove excess fixative, and then the samples were dehydrated in ascending graded concentrations of ethanol, cleared in xylene and embedded in paraffin wax. Sections of $4 \mu \mathrm{m}$-thick were cut by using SLEE Mainz Cut 5062 microtome, dewaxed in xylene $(2 \times 30$ $\mathrm{min})$, rehydrated in a descending series of ethanol $(100,90,80,70$ $\%)$, and washed by distilled water. The sections were then stained with Haematoxylin and Eosin (H\&E) stain for general histological examination, ${ }^{19}$ as described by Bancroft \& Gamble. ${ }^{20}$ The sections were dehydrated after staining in an ascending series of ethanol $(70 \%$, $95 \%$, and $100 \%)$, cleared in xylene ( $2 \times 10 \mathrm{~min})$ and mounted with DPX. The sections were then examined with light microscope, and digital images were acquired.

\section{Morphometrical and statistical analyses}

Morphometrical analyses including the length and width of the intestinal villi, as well as crypts depth were applied by using Image $\mathbf{J}$ image processing software. The statistical analyses were carried out using GraphPad Prism 6 Software package and were presented as mean \pm SD. Student's t-test was used for statistical comparisons and significant differences were obtained when $p<0.05$.

\section{Results}

\section{Performance and productivity}

The laying hens' performance results were illustrated in Table 3. A significant difference was reported in egg production for DPP supplemented group compared with control group throughout the experimental period. The significant improvement of the egg weight, egg mass, and feed conversion ratio (FCR) were also recorded. DPP supplemented group revealed a significant effect in cumulative eggs production (egg/layer) in three phases and throughout the experiment period. Feed intake of hens allotted onto DPP supplemented diet began to decrease from the second period, and feed consumption per egg were decreased along the experiment. As the feed intake decreased, the DPP supplemented laying hens performance was progressed compared to that of the control one, where live body weight was significantly increased (Table 4), and improvement of digestibility were recorded as well. 
Table 3 Effect of dietary DPP supplementation on egg production, weight, feed intake, egg mass and FCR of Egyptian Fayoumi laying hens

\begin{tabular}{|c|c|c|c|}
\hline Parameters & Period & Control group & Treated group \\
\hline \multirow{4}{*}{ Egg weight } & $\left.\right|^{\text {st }}$ & $42.28 \pm 0.65^{b}$ & $45.77 \pm 0.24^{a}$ \\
\hline & $2^{\text {nd }}$ & $41.62 \pm 0.5^{b}$ & $45.53 \pm 0.19^{a}$ \\
\hline & $3^{\text {rd }}$ & $41.82 \pm 0.7^{b}$ & $45.57 \pm 0.2 \mathrm{I}^{\mathrm{a}}$ \\
\hline & Collective & $4 I .97 \pm 0.3 I^{b}$ & $45.64 \pm 0.13^{a}$ \\
\hline \multirow{4}{*}{ Egg No. } & $I^{\text {st }}$ & $213 \pm 4.03^{b}$ & $228 \pm 0.82^{\mathrm{a}}$ \\
\hline & $2^{\text {nd }}$ & $214 \pm 3.37^{b}$ & $231.25 \pm 1.89^{a}$ \\
\hline & $3^{\text {rd }}$ & $215 \pm 2.94^{b}$ & $232.5 \pm 0.58^{\mathrm{a}}$ \\
\hline & Collective & $214.08 \pm 3.23^{b}$ & $230.58 \pm 2.28^{a}$ \\
\hline \multirow{4}{*}{ Egg production \% } & $I^{\text {st }}$ & $60.93 \pm 1.15^{b}$ & $65.14 \pm 0.23^{\mathrm{a}}$ \\
\hline & $2^{\text {nd }}$ & $61.14 \pm 0.96^{b}$ & $66.07 \pm 0.54^{\mathrm{a}}$ \\
\hline & $3^{\text {rd }}$ & $61.43 \pm 0.84^{b}$ & $66.43 \pm 0.16^{\mathrm{a}}$ \\
\hline & Collective & $60.17 \pm 0.92^{b}$ & $65.88 \pm 0.65^{*}$ \\
\hline \multirow{4}{*}{ Feed intake (g/d/hen) } & $I^{\text {st }}$ & $98 \pm 2.16$ & $98.25 \pm 0.96$ \\
\hline & $2^{\text {nd }}$ & $100.5 \pm 1.73$ & $99.75 \pm 0.5$ \\
\hline & $3^{\text {rd }}$ & $104.5 \pm 1.0$ & $102.25 \pm 0.5$ \\
\hline & Collective & $101 \pm 3.06$ & $100.08 \pm 1.75$ \\
\hline \multirow{4}{*}{$\begin{array}{l}\text { Feed consumption } \\
\text { per egg }(g)\end{array}$} & $I^{\text {st }}$ & $160.39 \pm 6.43^{b}$ & $150.82 \pm 1.33^{\mathrm{a}}$ \\
\hline & $2^{\text {nd }}$ & $164.39 \pm 3.35^{\mathrm{b}}$ & $150.98 \pm 1.33^{\mathrm{a}}$ \\
\hline & $3^{\text {rd }}$ & $170.34 \pm 3.9^{b}$ & $154.16 \pm 0.76^{a}$ \\
\hline & Collective & $|65.22 \pm 5.9|^{b}$ & $151.99 \pm 1.89^{a}$ \\
\hline \multirow{4}{*}{$\begin{array}{l}\text { Average No. of egg/ } \\
\text { hen/week }\end{array}$} & $\left.\right|^{\text {st }}$ & $4.27 \pm 0.08^{b}$ & $4.56 \pm 0.02^{\mathrm{a}}$ \\
\hline & $2^{\text {nd }}$ & $4.28 \pm 0.07^{b}$ & $4.63 \pm 0.04^{\mathrm{a}}$ \\
\hline & $3^{\text {rd }}$ & $4.3 \pm 0.06^{b}$ & $4.65 \pm 0.0 \mathrm{I}^{\mathrm{a}}$ \\
\hline & Collective & $4.28 \pm 0.07^{b}$ & $4.6 I \pm 0.05^{\mathrm{a}}$ \\
\hline \multirow{4}{*}{ Egg mass g/hen/day } & $I^{\text {st }}$ & $25.79 \pm 0.57^{b}$ & $29.82 \pm 0.19^{a}$ \\
\hline & $2^{\text {nd }}$ & $25.56 \pm 0.3^{b}$ & $30.12 \pm 0.2^{\mathrm{a}}$ \\
\hline & $3^{\text {rd }}$ & $25.67 \pm 0.25^{b}$ & $30.28 \pm 0.12^{\mathrm{a}}$ \\
\hline & Collective & $25.67 \pm 0.37^{b}$ & $30.07 \pm 0.26$ \\
\hline \multirow{4}{*}{ FCR (g feed/egg mass) } & $\left.\right|^{\text {st }}$ & $3.8 \pm 0.16^{b}$ & $3.30 \pm 0.03^{a}$ \\
\hline & $2^{\text {nd }}$ & $3.93 \pm 0.07^{b}$ & $3.3 \pm 0.02$ \\
\hline & $3^{\text {rd }}$ & $4.07 \pm 0.05^{b}$ & $3.38 \pm 0.03^{\mathrm{a}}$ \\
\hline & Collective & $3.94 \pm 0.15^{\mathrm{b}}$ & $3.33 \pm 0.04^{\mathrm{a}}$ \\
\hline
\end{tabular}

*There is a significance difference between the two groups in the parameters values with different superscripts.

\section{Apparent nutrients digestibility}

Digestibility was estimated to determine the efficiency of the digestion and retained amount from each nutrient in the body. The apparent digestibility of dry matter, crude fiber, crude protein, nitrogen free extract and ether extract were significantly improved with DPP supplementation for Fayoumi laying hen throughout the experimental period (Table 5).

Table 4 Effect of dietary DPP supplementation on body weight

\begin{tabular}{lll}
\hline Body weight & Control group & Treated group \\
\hline Initial weight $(\mathrm{gm})$ & $1411 \pm 27.7$ & $1400 \pm 20$ \\
Final weight $(\mathrm{gm})$ & $1590 \pm 62.93^{\mathrm{b}}$ & $1694 \pm 25.5^{\mathrm{a}}$ \\
Weight gain & $185 \pm 9.1^{\mathrm{b}}$ & $294 \pm 28.4^{\mathrm{a}}$ \\
\hline
\end{tabular}

The parameters values with different superscripts have a significance difference between the two groups.

Table 5 Effect of dietary DPP supplementation to Egyptian Fayoumi laying hens on nutrient digestibility

\begin{tabular}{lll}
\hline Parameters & Control group & Treated group \\
\hline Dry matter & $73.5 \pm 1.1^{\mathrm{b}}$ & $76.61 \pm 0.95^{\mathrm{a}}$ \\
Crude protein & $85.25 \pm 0.25^{\mathrm{b}}$ & $88 \pm 0.32^{\mathrm{a}}$ \\
Ether extract & $80.25 \pm 1.1^{\mathrm{b}}$ & $84.2 \pm 1.0 \mathrm{I}^{\mathrm{a}}$ \\
Crude fiber & $20.12 \pm 0.5^{\mathrm{b}}$ & $24 \pm 0.48^{\mathrm{a}}$ \\
Nitrogen free extract & $79.25 \pm 0.5^{\mathrm{b}}$ & $83 \pm 1.12^{\mathrm{a}}$
\end{tabular}

The parameters values with different superscripts have a significance difference between the two groups.

\section{Immune response}

Data illustrated in Table 6 showed that the treated group produced higher total antibodies titer and IgM titer against SRBCs at 7 and 14 days after the $1^{\text {st }}$ and $2^{\text {nd }}$ injection compared with control group. Concerning to $\mathrm{IgG}$, the treated group reported higher titer against SRBCs at the $14^{\text {th }}$ day after the $1^{\text {st }}$ injection and at the $7^{\text {th }}$ day after the $2^{\text {nd }}$ injection while there is no difference between the control and treated groups in IgG titer against SRBCs at the $7^{\text {th }}$ day after the $1^{\text {st }}$ injection and at the $14^{\text {th }}$ day after the $2^{\text {nd }}$ injection.

Table 6 Effect of dietary DPP supplementation to Egyptian Fayoumi laying hens on totalantibodies, IgGand IgM

\begin{tabular}{|c|c|c|c|c|c|}
\hline \multicolumn{2}{|c|}{ Parameters } & \multirow{2}{*}{$\begin{array}{l}\text { Day } 7 \text { p I }^{\text {st }} \\
3.9^{b}\end{array}$} & \multirow{2}{*}{$\begin{array}{l}\begin{array}{l}\text { Day I4 } \\
\text { l I }^{\text {st }}\end{array} \\
3.5^{b}\end{array}$} & \multirow{2}{*}{$\begin{array}{l}\begin{array}{l}\text { Day } 7 \\
\text { p2 }^{\text {nd }}\end{array} \\
5.6^{b}\end{array}$} & \multirow{2}{*}{$\begin{array}{l}\text { Day I4 } \\
\text { p2 }\end{array}$} \\
\hline $\begin{array}{l}\text { Total } \\
\text { antibodies }\end{array}$ & CG & & & & \\
\hline & TG & $4.3^{\mathrm{a}}$ & 4:00 AM & $6.1^{\mathrm{a}}$ & $4.4^{\mathrm{a}}$ \\
\hline \multirow[t]{2}{*}{$\lg G$} & CG & 2.3 & $1.8^{b}$ & $2.2^{\mathrm{b}}$ & 2.2 \\
\hline & TG & 2.3 & $2.1^{a}$ & 2.6 & 2.2 \\
\hline \multirow[t]{2}{*}{$\lg M$} & CG & $1.6^{\mathrm{b}}$ & $1.7^{b}$ & 3.4 & $1.5^{b}$ \\
\hline & TG & 2:00 AM & $1.9^{\mathrm{a}}$ & 3.5 & $2.2^{\mathrm{a}}$ \\
\hline
\end{tabular}

$\left.7 p\right|^{\text {st }} \& 7 p^{\text {nd }}=7$ days post first and second injection of SRBCs respectively. $14 \mathrm{pl}^{\text {st }} \& \mathrm{p} 2^{\text {nd }}=14$ days post first and second injection of SRBCs respectively. CG, control group;TG, treated group

The parameters values with different superscripts have a significance difference between the two groups. 


\section{Morphological parameters (duodenal and hepatic architecture)}

The duodenal wall illustrated the leaf-like intestinal villi, which are outgrowths of the mucosa, and project into the intestinal lumen. The lamina epithelialis consists of simple columnar epithelium with goblet cells. These villi were demonstrated longer and wider in the treated birds (Figure 1C) than the control ones (Figure 1A). The lamina propria is a connective tissue layer containing reticular fibers, smooth muscle fibers, numerous lymphatic cells, and crypts of Liberkuhn (intestinal glands), which are short simple tubular glands lined by simple columnar epithelium and goblet cells. These crypts were deeper in the treated group (Figure 1D) than the control one (Figure 1B). Moreover, the lymphatic infiltrations were more distinct in the treated birds (Figure 2B) than the control birds (Figure 2A) as a diffuse lymphocytic infiltrations as well as lymphoid follicles (Lymphoid nodules).

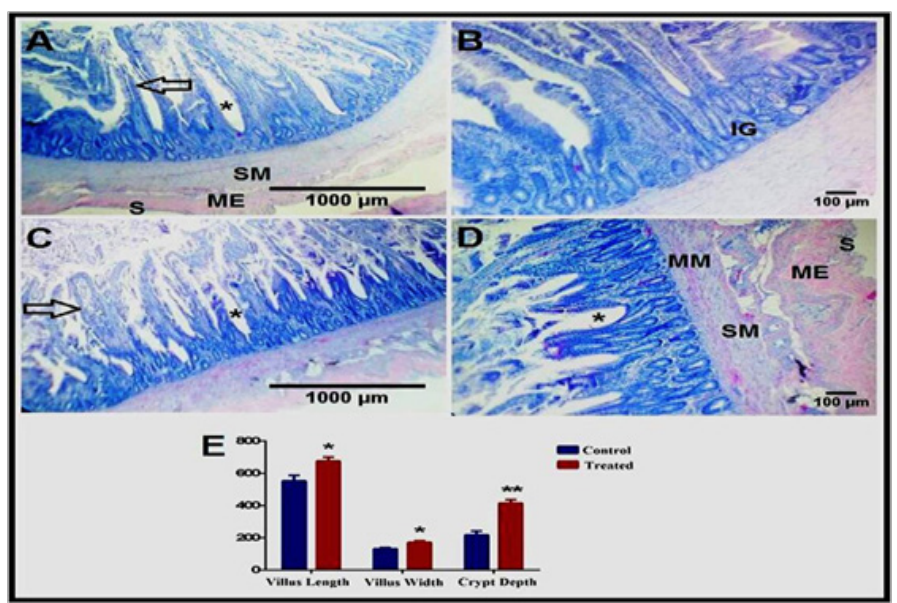

Figure I Effect of Date palm supplementation on duodenal morphology.

Cross sections of the duodenum of the control (A-B) and treated (C-D) groups showing the lamina epithelialis of the mucosa with the intestinal vill (black arrow) and crypts (asterisk), lamina propria with the intestinal glands (IG), muscularis mucosa (MM), submucosa (SM), muscularis externa (ME), and serosa (S). H\&E stain. (E) Morphometrical analysis of villi length and width, as well as crypt depth (in $\mu \mathrm{m}$ ).

$* P<0.05$ and $* * P<0.01$.

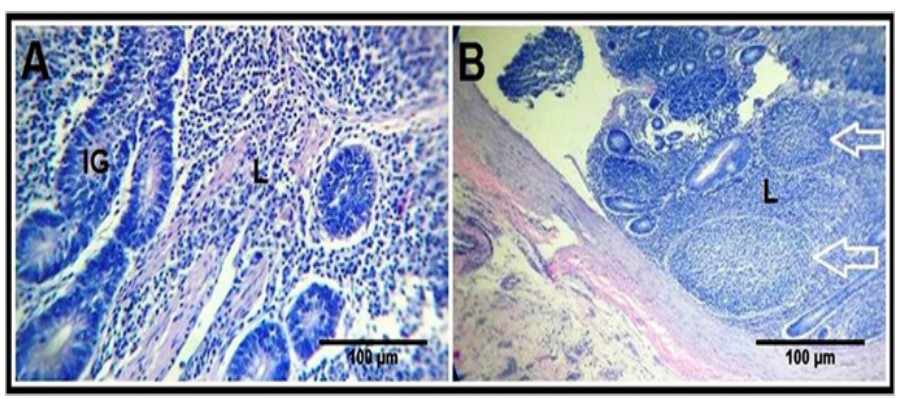

Figure 2 Effect of Date palm supplementation on lymphatics.

Cross sections of the duodenum of the control (A) and treated (B) groups showing the lymphocytic infiltrations $(L)$ in the duodenal mucosa, with the presence of lymphoid nodules (white arrow) in the treated birds. H\&E stain.
The mucosa includes an ill-developed layer of smooth muscle fibers, muscularis mucosa. The submucosa is a thin layer of connective tissue containing elastic fibers and numerous lymphocytes, while the muscularis layer consists of smooth muscle fibers. The most external layer of duodenal wall is the serosa (Figure 1A). The liver is surrounded by a thin capsule, and the interlobular connective tissue is scare so the hepatic lobules are not clear. The parenchyma is composed of several hepatic plates orienting radically around the central vein, and separated by hepatic sinusoids. Each hepatic plate is composed of two rows of hepatic cells that are hexagonal and contain a large, central, rounded nucleus. The hepatic lobules are separated by several portal areas. The liver of the treated group revealed increased lymphatic infiltrations (Figure 3B) compared to that of the control group (Figure 3A).

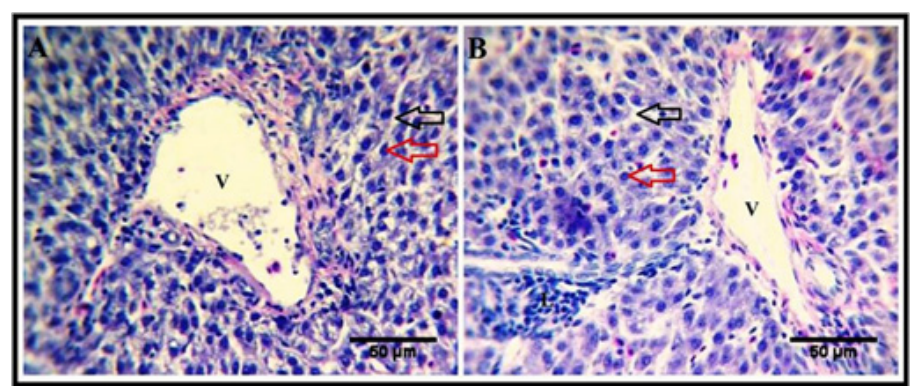

Figure 3 Effect of Date palm exudate supplementation on hepatic morphology.

Hepatic sections from both control (A) and treated (B) birds reveals that, the liver consists of a network of hepatocytes (red arrow) arranged in plates separated by vascular sinusoids (black arrow). V, branches of portal vein. Note presence of lymphocytic infiltrations $(L)$ in the hepatic tissues of the treated group, H\&E stain.

\section{Discussion}

\section{Performance, productivity, and intestinal morphology}

The significant improvement of the hen production with DPP supplementation was previously explained as a response to the presence of high concentration of estradiol and estrogen hormone. ${ }^{8}$ Furthermore, DPP have ability to increase growth of ovary, oviducts and their functions resulting in increasing of egg production. ${ }^{9}$ Also, Walzem et al., ${ }^{21}$ reported that FSH and LH hormones increased by addition of DPP. As a result to these explanations, supplementation of layers hens with DPP increase reproductive hormones that cause high laying sequences ${ }^{8}$ and increase eggs lying number. Besides the above response for improvement productivity, the histological examination of the intestinal lumen indicated increasing of the villi length and crypt depth, where both are the places of digestion and absorption, reflecting on progression of both functions and increased body weight, egg weight, production and FCR.

On the other hand, the metabolism was better also by improvement of the liver activity. The significant stimulant response in eggs weight of the treated group throughout the experimental periods could be related to growth of the ovarian epithelium ${ }^{22}$ as a response to liver secretions of lipids, proteins and hormones, caused by increased estrogen effects on the liver. These explanations were confirmed by the histological features that clarified the activity of the liver. Decrease the feed intake of the treated group from the second phase till end of the experiment was supposed to be due to the over growth of villi (place of digestion 
and absorption) that reflect better usage of feed intake and in return decrease amount of feed. Feed conversion (FCR, g feed/egg mass) showed a significant improvement for DPP supplemented group in all periods, in general mean, these results came from increasing in eggs weight without increasing in feed intake in first phase, while feed intake decreased from second till end of experiment.

\section{Apparent nutrients digestibility}

The significant increase in body weight for DPP treated group may be attributed to high efficiency of utilizing feed and high digestibility. The digestibility of dry matter, crude protein, ether extract, crude fiber and NFE were significantly progressed as a result of increase villi length and crypt depth, and in general due to the antioxidant effect of DPP, which decreases the peroxides and free radicals that found in high concentration in active organs as testis, ovaries and in intestinal epithelium, decreases life span of cells, and leads to aging with short villi and shallow crypt. ${ }^{23,24}$ The oxidative lesions inhibits pancreatic enzyme through conformational modifications of proteins. Consequently, the presence of antioxidants (polyphenolics and Flavonoides of DPP) could partially face denaturation of protein due to oxidation and could improve nutrients digestion and retention in body. These free radicals and peroxides cause destruction of cell membranes. ${ }^{23}$ Finally, DPP supplementation initiated increase of intestinal cells life span that was reflected as long villi and deep crypt, besides increase of blood supply of intestine and general function of both liver and pancreas.

\section{Immune Response and lymphatic infiltrations}

Total antibodies titer of the treated group was more significantly improved than those of control group, whereas, the treated group produced higher titer against SRBCs at the $14^{\text {th }}$ day after the $1^{\text {st }}$ injection and at the $7^{\text {th }}$ day after the $2^{\text {nd }}$ injection while there is no difference between the control and treated groups in IgG titer against SRBCs at the $7^{\text {th }}$ day after the $1^{\text {st }}$ injection and at the $14^{\text {th }}$ day after the $2^{\text {nd }}$ injection. Okada \& Yamamoto ${ }^{25}$ recorded high antibody titer to SRBC and lip polysaccharide injection and high IgG level that was confirmed by Martin et al., ${ }^{26}$ results, with regard to IgM antibodies titer against SRBCs, there were significant difference between the treated and control groups. This immune response was confirmed by the histological changes that showed a massive infiltration of lymphocytes around the intestinal epithelium and in liver.

The lumen of gastrointestinal tract (GIT) is exposed to potentially pathogenic microorganisms that present in external environment. Lymphocytes have important role in the immune surveillance of gastrointestinal tract, besides generation of immune response in the mucosa. The lymphoid nodules, termed Peyer's patches, are a critical part of gut belongs to lymphoid tissue, which placed in the lowest part of small intestine, and could be found in the duodenum. ${ }^{27}$ The current work revealed the beneficial effect of Date palm supplementation on the duodenal and liver morphology. Much lymphocytes infiltrations and nodules were illustrated in both mucosa of the duodenum and parenchyma of the liver of treated birds. These previous mentioned changes reflect the role of date palm in the immune system modulation and stimulation. ${ }^{28,29}$ Among the immune modulatory activities of date-derived phenolics is anti-allergic effect that can suppress the hypersensitive immune response. ${ }^{30}$ Moreover, selenium in dates is assumed to stimulate the immune systems. ${ }^{31}$
Date palm and its flavonids composition have a preventive effect against the diseases through the antibacterial, antifungal, antioxidant, and anti-tumour activities. ${ }^{32-34}$ Date fruit is also a good source of important phytochemicals, including carotenoids, phenolics, and flavonoids. It has other medicinal values, including gastroprotective and hepatoprotective. ${ }^{35}$ These latter activities were confirmed in the current study.

\section{Conclusion}

In conclusion, dietary supplementation of Fayoumi laying hens with DPP can improve egg production and general health. These positive impacts were confirmed by progression of intestinal and hepatic architecture, immune response, growth performances and digestibility together with improvement of egg mass and FCR in comparison to non supplemented hens.

\section{Acknowledgement}

None.

\section{Conflicts of interest}

Author declares there is no conflict of interest.

\section{References}

1. Aboua YG, du Plessis SS, Reichgelt $P$, et al. The in vitro effects of superoxide, some commercially available antioxidants and red panlm oil on sperm motility. Asian J Androl. 2009;11(6):695-702.

2. Al-Farsi M, Alasalvar C, Morris A, et al. Comparison of antioxidant activity, anthocyanins, carotenoids, and phenolics of three native fresh and sun-dried date (Phoenix dactylifera L.) varieties grown in Oman. $J$ Agric Food Chem. 2005;53(19):7592-7599.

3. Lotito SB, Frei B. Consumption of flavonoid-rich foods andincreased plasma antioxidant capacity in humans: cause, consequence, or epiphenomenon? Free Radic Biol Med. 2006;41(12):1727-1746.

4. Aydilek N, Aksakal M, Karakilcik AZ. Effects of testosterone and vitamin E on the antioxidant system in rabbit testis. Andrologia. 2004;36(5):277281 .

5. Guo H, An C, Gan Z, et al. Experimental study on antioxidant and calcium channel blockade preventing testicular fibrosis in rats. Zhonghua Nan Ke Xue. 2004;10(11):857-863.

6. Al-Qarawi AA, Mousa HM, Ali BE, et al. Protective effect of extracts from dates (Phoenix dactylifera L.) on carbon tetrachloride-Induced Hepatotoxicity in rats. Intern J Appl Res Vet Med. 2004;2(3):176-180.

7. Mousa MA, Sayed HH, Osman AS. The Impact of palm pollen and Ginkgo Biloba supplementation on productive performance, biochemical parameters and immune response of broilers. JIARM. 2016;4():236-251.

8. Arhaem SH. Effects of use different level from water extract of DATE PALM POLLEN on ovary function and some production CHARACTERISTICS. Al-furat Agric Sci. 2004;6:98-103.

9. Ammar QS, Mahdi SJ, Ali HM, et al. The Effect of Using Different Levels from Date Palm Pollen in Diet on Productive Performance and Some Eggs Quality Measurements for Layer Hens Lohman. Anim Vet Sci. 2015;3(6-1):1-4.

10. Metwaly MS, Dkhil MA, Al-Quraishy S, et al. Protective Effects of Palm Pollen Aqueous Extract Against Eimeria papillata Induced Intestinal Damage in Mice. Pakistan J Zool. 2015;47(4):971-979. 
11. Yamauchi KE, Incharoen $\mathrm{T}$, Yamauchi $\mathrm{K}$. The relationship between intestinal histology and function as shown by compensatory enlargemen of remnant villi after midgut resection in chickens. Anat Records. 2010;293(12):2071-2079.

12. Hodges RD. The histology of the fowl. Academic press: London; 1974.

13. King AS, Mclelland J. Outlines of avian anatomy. Bailliere Tindall: London; 1975.

14. AOAC(Association of Official Analytical Chemists). Official Methods of Analysis. $16^{\text {th }}$ edn. Washington DC. 2000

15. Petry H, Rapp W. Zur Problematik der Chromoxidebestimmung in erdauungsversuchen. $\mathrm{Z}$ Tierphysiol Tierernähr. Futterm Kde. 1971;27:181-189.

16. Saxena VK, Singh H, Pal SK, et al. Genetic studies on primary antibody response to sheep erythrocytes in guinea fowl. British Poult Sci.1997;38(2):156-158.

17. Yamamoto Y, Glick B. A comparison of the immune response between two lines of chickens selected for differences in the weight of the bursa of Fabricius. Poult Sci. 1982;61(10):2129-2132.

18. Qureshi MA, Havenstein GB. A comparison of the immune performance of a 1991 commercial broiler with a 1957 randombred strain when fed "typical" 1957 and 1991 broiler diets. Poult Sci. 1994;73(12):1805-1812.

19. Harris HR. On the rapid conversion of haematoxylin into haematein in staining reactions. J Appl Microsc. 1900;3(3):777-780.

20. Bancroft JD, Gamble M. Theory and practice of histological techniques. $5^{\text {th }}$ edn. Elsevier Health Sciences publisher; London: 2008.

21. Walzem RL, Hansen RJ, Williams DL, et al. Estrogen Induction of VLDL assembly in egg-laying hens. $J$ Nut. 1999;129(2s):467-472.

22. Ahmed MB, Hasona NAS, Selemain H. Protective effects of extract from dates (Phoenix dactylifera L.) and. ascorbic acide on thio actamide -induced hepatotoxicity in rats. Iranian J Pharm Res. 2008;7:193-201.

23. NRC. Nutrient requirements of poultry. $9^{\text {th }}$ Revised edn. National Academy Press: Washington DC; 1994.p. 19-34.
24. Ciftci M, Ertas ON, Guler T. Effects of Vitamin E and Vitamin C dietary supplementation on egg production and egg quality of laying hens exposed to a chronic heat stres. Revue Med Vet. 2005;156:107-111.

25. Okada I, Yamamoto Y. Immunocompetence and Marek's disease resistance in three pairs of chicken lines selected for different immunological characters. Poult Sci. 1987;66(5):769-773.

26. Martin A, Gross WB, Siegel PB. IgG and IgM responses in high and low antibody selected lines of chickens. J Heredity. 1989;80(3):249-252.

27. Cornes JS. Number, size, and distribution of Peyer's patches in the human small intestine: Part I The development of Peyer's patches. Gut. 1965;6(3):225-229.

28. Mansouri A, Embarek G, Kokkalou E, et al. Phenolic profile and antioxidant activity of the Algerian ripe date palm fruit (Phoenix dactylifera). Food Chem. 2005;89(3):411-420.

29. El Hadrami A, Al-Khayri JM. Socioeconomic and traditional importance of date palm. Emirates J Food Agric. 2012;24:371-385.

30. Noguchi Y, Fukuda K, Matsushima A, et al. Inhibition of Df-protease associated with allergic diseases by polyphenol. J Agric Food Chem. 1999;47(8):2969-2972.

31. Al-Showiman SS. Ghetha wa Saha (Date, Food and Health). Dar AlKhareji Press: Saudi Arabia; 1998.

32. Pietta PG. Flavonoids as antioxidants. J Nat Products. 2000;63(7):10351042 .

33. Rahmani AH, Aly SM, Ali H, et al. Therapeutic effects of date fruits (Phoenix dactylifera) in the prevention of diseases via modulation of anti-inflammatory, anti-oxidant and anti-tumour activity. Int J Clin Exp Med. 2014;7(3):483-491

34. Al-Alawi RA, Al-Mashiqri JH, Al-Nadabi JS, et al. Date Palm Tree (Phoenix dactyliferaL.). Front Plant Sci. 2017;8:845.

35. Tang ZX, Shi LE, Aleid SM. Date fruit: chemical composition, nutritional and medicinal values, products. J Sci Food Agric. 2103;93(10):23512361. 